\title{
ESTIMANDO A NECESSIDADE: OS ORÁCULOS DE IFÁ E A VERDADE EM HAVANA*
}

Martin Holbraad

Aqui na Europa, quando digo às pessoas que fui para Havana trabalhar sobre certos cultos, cujos praticantes pensam que os oráculos dizem a verdade sobre as coisas, vejo-me quase invariavelmente intimado a responder acerca de mim mesmo: "e você? você acha que os oráculos funcionam?" Eu ao mesmo tempo adoro e detesto esta pergunta. Uma das razões por que gosto tanto dela, sobretudo quando é feita por, digamos, um químico de minha universidade, é que, em sua mistura de indiscrição e descrença, ela não me deixa esquecer que a antropologia tem mesmo algo a dizer - até para os químicos. Por um momento, eu, metonímia de meu próprio objeto de estudo, torno-me tão fascinante para meu amigo químico quanto esse objeto o é para mim, o antropólogo. E, enquanto antropólogo, estou em boa e venerável companhia, já que não é absurdo dizer que, quando Frazer e Tylor deram o pontapé inicial de nosso jogo disciplinar, explicando por que os selvagens podiam ser crédulos a ponto de pensar que coisas como os oráculos funcionavam, eles estavam respondendo ao mesmo tipo de inquietude da psique vitoriana que se espera que eu, agora, responda, ao falar com meu químico colega. É claro que os químicos de hoje nem piscam quando ouvem dizer que, no Caribe, as pessoas acreditam em oráculos - e por essa duvidosa serenidade eles bem poderiam agradecer aos antropólogos. Mas a persistência da questão ("sim, mas você acredita em oráculos?") mostra que os motivos da inquietação ainda estão lá.

Eu certamente gostaria ainda mais da pergunta se pudesse responder a ela emprestando ao meu interlocutor um livro, não de Frazer ou Tylor, mas de algum dos muitos antropólogos contemporâneos que, ao cabo de análises rigorosas, tivessem conseguido transformar crenças estranhas em algo menos perturbador. Acontece que não posso; os antropólogos, penso eu, ainda não foram capazes de produzir uma análise realmente satisfatória da verdade oracular ${ }^{1}$. No entanto, essa minha afirma- 
ção (que defenderei apenas no que concerne a um exemplo específico) não explica por que a provocação sobre minhas crenças me causa tanto mal-estar, isto é, por que detesto a pergunta tanto quanto a aprecio. O que incomoda nesse desafio é que ele tende a me enredar em um double bind. Se digo que não acredito em oráculos, acabo rapidamente com a inquietação do meu interlocutor, mas por meio de algo que, na verdade, é uma mentira. Pois, em um sentido importante, eu acredito em oráculos. Mas se lhe disser isto, crio todas as condições para um mal-entendido, uma vez que o sentido em que confio em oráculos é muito diferente do sentido mais sensacionalista que lhe interessa.

O objetivo do presente artigo é fornecer os esclarecimentos necessários à dissipação de tal mal-entendido.

A razão pela qual introduzi a discussão sobre os oráculos de Ifá mediante exemplos familiares a todo antropólogo (a pergunta do meu hipotético químico) não é retórica. O ponto se liga a um argumento proposto recentemente por Eduardo Viveiros de Castro (2002) como parte de sua crítica àquilo que chama de "solução antropológica clássica" para o problema de como levar a sério afirmações espantosas do tipo "os pecaris são humanos" - seu exemplo ameríndio predileto. Tendo em mente Durkheim, Lévi-Strauss e Sperber, entre outros, ele sustenta que a 'solução clássica' é um conjunto de variações em torno de um pressuposto comum, a saber, que, se levamos a sério os nativos quando dizem ou fazem coisas que os antropólogos consideram irracionais, precisamos fazê-lo apesar daquilo que os nativos dizem ou fazem. Incapazes de admitir que os pecaris possam ser humanos, os antropólogos concluem que sua única opção é enunciar as condições sob as quais os nativos poderiam entreter seriamente noções tão estapafúrdias.

O pressuposto crucial aqui, nota Viveiros de Castro, é que, quando os antropólogos dizem (consigo mesmos) "é claro que os pecaris não são humanos", eles têm em mente os mesmos conceitos que têm os nativos, ao dizerem que os pecaris são humanos. Se assim não fosse, os antropólogos não teriam como julgar a veracidade ou falsidade dos enunciados dos nativos. Ou, para utilizar uma linguagem mais filosófica, o pressuposto é que os enunciados "os pecaris não são humanos" (como os antropólogos sabem) e "os pecaris são humanos" (como os nativos pretendem) lançam mão de termos que possuem 'intensões' mais ou menos idênticas e que a oposição entre eles é verofuncional (seus valores sendo, respectivamente, verdadeiro e não verdadeiro) ${ }^{2}$, porque o papel de cada enunciado é fixar semanticamente a 'extensão' dos termos envolvidos (cf. Viveiros de Castro 2002:134) ${ }^{3}$. E de fato, segundo essa interpretação, o 'er- 
ro' dos nativos seria palpável. Embora os conceitos de 'pecari' e 'humano' sejam tão distintos para eles quanto o são para nós, os nativos insistiriam em aplicar equivocadamente esses conceitos (ou seja, em avaliar erroneamente sua extensão), fundindo de maneira bizarra as duas classes em enunciados do tipo "os pecaris são humanos", que são entendidos aqui como fazendo afirmações empíricas em vez de conceituais. A tarefa da análise antropológica, portanto, seria explicar por que os nativos poderiam, digamos assim, entender errado seus próprios conceitos. O que significa dizer que o 'problema' antropológico seria de cabo a rabo um problema epistemológico.

Ora, como essa tentativa de interpretação sugere, a abordagem 'clássica' não é, em si mesma, insustentável. Entretanto, ela é duplamente (pelo menos) implausível. Precisaríamos de uma muito boa razão para esperar que gente tão diferente de nós, e de tantas maneiras, quanto os ameríndios, compartilhasse não obstante nossos próprios conceitos conceitos tão importantes como 'humano' - ou, inversamente, que conceitos tão peculiarmente indígenas como 'pecari' nos fossem evidentes. Também precisaríamos de uma boa razão que explicasse por que os índios compreenderiam de modo tão sistematicamente errado as implicações empíricas desses conceitos. Afinal, como nos lembra Viveiros de Castro, os pecaris não são apenas humanos; "[eles] andam em bando... têm um chefe... são barulhentos e agressivos [...] e assim por diante" (2002:136). Assim, longe de serem equívocos pontuais, os 'erros' ameríndios seriam não apenas sérios, como seriais: erros em cima de erros. Ora, como se sabe, há explicações disponíveis que nos livrariam, em princípio, de ambas as implausibilidades: um exemplo seriam as tentativas dos antropólogos cognitivistas de definir um repertório conceitual humano básico; outro exemplo, o velho argumento popperiano acerca do caráter "fechado" dos "sistemas de crença" místicos (cf. Horton 1967). O problema é que essas saídas teóricas, a despeito de seus méritos, acabam dando a impressão de estar, digamos, batendo no martelo com o prego, quando atentamos para a real inverossimilhança de seus explananda.

É preciso admitir que, se não houvesse alternativa, teríamos que engolir as implausibilidades - ou, pelo menos, aceitar as teorias desencantadoras que elas engendram. Mas, como mostra Viveiros de Castro, há uma opção devidamente radical, que é a seguinte: e se estipulássemos que a perplexidade do analista diante dos enunciados nativos não é causada por uma discordância epistemológica acerca da correta aplicação empírica de certos conceitos compartilhados (ou seja, uma diferença de opinião), mas, antes, pela absoluta alteridade dos conceitos envolvidos? 
Assim, se, de acordo com a presente interpretação, a posição clássica resulta da idéia de que termos como 'pecari' e 'humano' têm a mesma intensão para os nativos e para o analista, então a alternativa proposta por Viveiros de Castro é sua negação direta: os termos têm intensões diferentes para o analista e para os nativos - e é precisamente por isso que os enunciados nativos soam genuinamente bizarros ao analista.

Viveiros de Castro apresenta vários argumentos em favor dessa inversão conceitual; irei me concentrar aqui em dois de seus aspectos positivos, antes de discutir criticamente algumas de suas implicações para minha própria estratégia. Ao recusar a primeira implausibilidade da abordagem clássica - a saber, que os conceitos dos nativos têm que ser basicamente os mesmos que os nossos — , a reivindicação de uma alteridade intensional desfaz também a segunda - isto é, que os nativos aplicam sistematicamente mal seus próprios conceitos. Pois, uma vez aberta a possibilidade de que os conceitos nativos possam ser diferentes dos nossos, enunciados como "os pecaris são humanos" não precisam mais ser vistos como tentativas de se 'aplicar' — de determinar a extensão de - termos predefinidos ('pecaris' e 'humanos'). Ao contrário, eles podem ser vistos como tentativas, por parte dos nativos, de expressar o sentido de seus próprios conceitos, ou seja, de defini-los intensionalmente (cf. Wagner 1972:5-8). Não se tratando aqui, portanto, de 'aplicações' extensivas, a possibilidade de um erro nativo nem entra em discussão. A rigor, já que enunciados como "os pecaris são humanos" visam definir o que conta como 'pecari' (e, segundo essa definição bizarra, também como 'humano'), eles devem ser entendidos como enunciados ontológicos, do mesmo tipo que, por exemplo, a definição cartesiana do Eu como res cogitans.

A segunda vantagem da inversão de Viveiros de Castro é que ela sugere um programa analítico muito mais fecundo do que o seria uma mera inversão da imagem 'clássica'. Ao retirar os parênteses, por assim dizer, que mantêm em suspenso o sentido dos enunciados nativos, e ao instituí-lo como objeto principal da análise antropológica, Viveiros de Castro propõe efetivamente um campo conceitual que é novo por definição. Considere-se em que deve consistir a tarefa da análise segundo essa visão. Em lugar de enunciar as condições do erro nativo (condições epistêmicas, cognitivas, sociológicas, políticas ou outras), a tarefa analítica passa a ser a de elucidar novos conceitos — estes também novos por definição. De fato, note-se que esse projeto é necessariamente muito diferente da noção, familiar em virtude das abordagens ditas relativistas, de 'tradução cultural' ou 'descrição êmica'4. Pois as idéias de tradução ou descrição dependem do pressuposto de que conceitos de tradições inte- 
lectuais alheias devem ter equivalentes suficientemente familiares, como se o repertório conceitual 'deles' devesse em última análise ser revelado como isomórfico ao 'nosso'. O que seria a terceira implausibilidade miraculosa: verstehen... E isto, é claro, é precisamente o oposto do que argumenta Viveiros de Castro.

A melhor maneira, talvez, de encararmos a análise proposta por Viveiros de Castro é como se ela fosse uma versão etnograficamente motivada daquilo que os filósofos - especialmente os analíticos - tendem a ver como sua ocupação característica, a saber, a 'análise conceitual'. Esta é, certamente, a direção para a qual ele mesmo parece estar apontando, quando define a antropologia como uma espécie de experimento mental envolvendo crucialmente uma dimensão de 'ficção':

\footnotetext{
Em que consiste tal ficção? Ela consiste em tomar as idéias indígenas como conceitos, e em extrair dessa decisão suas conseqüências: determinar o solo pré-conceitual ou o plano de imanência que tais conceitos pressupõem, os personagens conceituais que eles acionam, e a matéria do real que eles põem (Viveiros de Castro 2002:123, ênfases no original).
}

A perspectiva é sedutora, mas pergunto-me se, com isso, Viveiros de Castro não está perto de invocar seu próprio milagre ex machina, uma vez que, tendo em vista a premissa condutora de sua abordagem, o que ele está efetivamente sugerindo é uma maneira de chegar até os pressupostos e/ou as conseqüências ontológicas de conceitos que, entretanto, ainda precisam ser definidos. De fato, devemos tratar as idéias indígenas como conceitos, mas, como vimos, o que se quer com isto é explicitar para nós, analistas - sua alteridade intensional. Sucede que as inferências ontológicas que Viveiros de Castro parece ter em mente não podem ser feitas de tal posição aporística. Na verdade, este é o ponto em que a analogia entre a análise antropológica e a filosófica se desfaz. Enquanto exercício intelectual autóctone, a filosofia pode se dar ao luxo de, ao testar os limites de conceitos familiares, criar novos conceitos não familiares; o 'novo', aqui, pode se apoiar sobre os ombros do 'velho'. O desafio antropológico, ao contrário, parece ser hiperfilosófico: espera-se que criemos novos conceitos (nossos) a partir de conceitos que para nós são igualmente novos (os dos nativos). Mas isso seria quase como uma criação ex nihilo...

Um quarto milagre ou implausibilidade, portanto? $\mathrm{O}$ argumento do presente artigo parte da premissa que não. Eu diria que as ferramentas metodológicas necessárias para os experimentos mentais a que Viveiros de Castro alude podem, de fato, ser extraídas do contraste entre os enun- 
ciados nativos e nossos pressupostos habituais. Considere-se a seguinte estratégia. De acordo com as "regras do jogo" de Viveiros de Castro, devemos aceitar que, enquanto antropólogos, estamos no escuro: começamos sem nada saber do sentido dos conceitos nativos. Mas conhecemos, de fato, duas coisas. Em primeiro lugar, conhecemos o sentido de nossos próprios conceitos ordinários (por exemplo, que os pecaris são animais suiformes da América tropical). Em segundo lugar, sabemos que um sintoma da diferença entre nossos conceitos e os dos nativos é que, em certos contextos (a saber, naqueles em que suas intensões diferem), nossas próprias traduções - ou antes, equivocações - dos conceitos nativos aparecem como enunciações de falsidades.

É possível argumentar que temos aqui os rudimentos de um método que permitiria nos aproximarmos de uma compreensão dos conceitos nativos e dos estranhos enunciados que os definem. Pois, tal como os filósofos, uma coisa que podemos fazer é transformar o sentido de nossos próprios conceitos. Sendo assim, cabe perguntar: e se, por meio da análise conceitual, alterássemos as premissas de nossos conceitos ('pecari', 'humano' etc.), transformando-os de tal modo que, quando usados para glosar enunciados nativos, eles produzissem enunciados verdadeiros? $\mathrm{O}$ experimento mental antropológico partiria, portanto, da questão: como mudar a intensão de nossos próprios termos para fazer com que se comportem, em termos verofuncionais, como os conceitos nativos parecem se comportar? Até que ponto temos que mudar nossos pressupostos acerca do que conta como 'pecari' antes de podermos, nós, dizer que os pecaris são humanos? A promessa aqui, certamente, não é a de nos apropriarmos dos conceitos nativos eles mesmos, mas de produzir equivalentes aproximados deles, no que seria uma espécie de simulação verofuncional. Isto não torna o projeto da análise menos fecundo. Afinal, o tipo de revolução copernicana aqui proposto tem, por definição, o objetivo de chegar a novos conceitos. Para facilitar a referência, proponho chamar esse método de 'ontográfico', indicando assim que ele oferece um meio de mapear as premissas ontológicas do discurso nativo.

Assim, nesse sentido metodológico limitado, eu discordaria da afirmação incondicional de Viveiros de Castro de que os juízos de verdade dos antropólogos são inteiramente irrelevantes para a análise.

Sou antropólogo, não suinólogo. [...] Quando um antropólogo ouve de um interlocutor indígena [...] algo como "os pecaris são humanos", a afirmação, sem dúvida, interessa-lhe porque ele 'sabe' que os pecaris não são humanos. Mas esse saber - um saber essencialmente arbitrário, para não dizer- 
mos burro - deve parar aí: seu único interesse consiste em ter despertado o interesse do antropólogo (Viveiros de Castro 2002:134-135).

A partir daí, afirma, os antropólogos deveriam deixar de lado seus próprios juízos de verdade e concentrar-se na tarefa de revelar os pressupostos ontológicos que subjazem aos enunciados dos nativos. Tendo em vista as considerações anteriores, no entanto, eu sustentaria que, logicamente falando, não há como avaliar as premissas dos enunciados nativos exceto à luz dos nossos, e que tais comparações devem, em última análise, ser guiadas por considerações verofuncionais.

O presente artigo tem por objetivo tornar clara a fecundidade desse método. Minha tarefa será fazer uma ontografia do conceito de verdade, tal como este se articula no oráculo de Ifá cubano. A partir dos comentários que acabo de fazer acerca do papel dos juízos de verdade no método ontográfico, a escolha do tema pode parecer singularmente recursiva. De fato, uma análise dos conceitos oraculares de verdade sugere comparações pertinentes com os tipos de conceitos de verdade em que os próprios antropólogos se apóiam em suas estratégias analíticas 5 — inclusive, notese, a própria 'ontografia'. Por definição, uma ontografia da verdade divinatória depende necessariamente de uma crítica dos conceitos de verdade que podem ser considerados ordinários, em um sentido geral ou 'comum'; mas o passo adicional de comparar a verdade divinatória aos conceitos de verdade em jogo no contexto da análise antropológica (ontográfica ou outra) não pode ser dado aqui. Afinal, como sugerido por meus embates anedóticos com os químicos, a adivinhação é bizarra o bastante para justificar um projeto ontográfico próprio e de pleno direito. As implicações meta-antropológicas pertinentes podem ser deixadas para investigações futuras.

No que se segue, começo traçando os contornos de minha abordagem a partir de uma discussão da teoria de Pascal Boyer sobre a adivinhação. Em seguida, apresento alguns fatos etnográficos sobre o oráculo cubano. Enfatizando a afirmação nativa de que o Ifá é infalível, proponho que os vereditos divinatórios devem ser entendidos como verdades necessárias, isto é, como enunciados que não poderiam não ser verdadeiros. A seção seguinte é dedicada a estabelecer que, do ponto de vista das concepções comuns da verdade, a necessidade modal dos oráculos só pode parecer um absurdo dogmático. Para os propósitos da análise ontográfica, este é um motivo suficiente para descartarmos tais concepções, avançando uma conceitualização alternativa que concorde (extensivamente) com as convicções dos informantes. Na última seção, essa tarefa 
é realizada a partir da etnografia: examinarei um complexo de conceitos e práticas associados ao oráculo a fim de avaliar as premissas que garantem a verdade e sua emergência na prática do Ifá. Observo que o que distingue a ontografia de uma mera especulação ontológica arbitrária é a tentativa de se extrapolar abstrações analíticas a partir do material etnográfico, em lugar de soterrá-lo sob uma pilha de conceitos filosóficos ocidentais.

A idéia central, portanto, é que as pretensões divinatórias de verdade são isentas de dúvida porque suas condições de verdade não se especificam com referência aos fatos. Ao contrário, a prática oracular exibe aquilo que denomino uma lógica não representativa ou 'movente' ['motile'], a qual pressupõe uma noção de verdade entendida não como correspondência transontológica entre o plano da representação e o plano do fato, mas como movimento proximal em um único plano ontológico, facultando os eventos revelatórios. Se tal afirmação parece, a esta altura, esotérica, é porque ainda não chegamos à etnografia. Antes de fazê-lo, entretanto, talvez seja útil marcar os termos dessa abordagem 'nãorepresentacionista', contrastando-a com uma tentativa relativamente recente de explicação da verdade oracular, proposta por Boyer. O argumento de Boyer também gira em torno da negação do papel da 'representação' nos contextos oraculares, mas de maneira bem diferente da que irei propor - e essa diferença pode ser instrutiva.

\section{Boyer sobre a verdade oracular}

Assim como seus argumentos sobre os fenômenos religiosos em geral (Boyer 1990; 1994; 2000; 2001), o argumento de Pascal Boyer sobre a prática divinatória gira em torno de uma premissa cognitiva, a saber, a de que explicar por que as pessoas pensam o que pensam - neste caso, por que pensam que os oráculos dizem a verdade - é, em última análise, uma questão de mostrar como suas mentes são capazes de entreter as idéias em causa, e como tendem a fazê-lo. A razão disso é que as idéias que os antropólogos normalmente descrevem de modo sumário como 'culturais' consistem, na realidade, em agregados muito complexos de representações mentais, disseminadas entre as populações humanas em conseqüência das características do cérebro humano, visto como o instrumento por excelência da representação mental (Sperber 1996), e de acordo com elas.

Conforme a essa premissa anticulturalista, Boyer descarta a questão geral (ou, como ele a chama, "epistêmica") de saber por que as pessoas 
acreditam em oráculos e passa a analisar os processos cognitivos envolvidos quando um dado indivíduo representa um pronunciamento divinatório (doravante, "veredito") como sendo verdadeiro (Boyer 1994:49-52). Esses processos, argumenta, podem ser vistos como uma variante peculiar daqueles que têm lugar quando da atribuição de valor de verdade a qualquer representação ordinária, por exemplo no decorrer de uma conversa. O primeiro ponto a notar sobre a estrutura cognitiva da atribuição de valor de verdade como tal é que ela é "metarepresentativa", isto é, concerne à capacidade da mente/cérebro de representar representações (Boyer 1994:243-245). Tomemos, por exemplo, as representações expressas quando as pessoas se comunicam entre si. Representar tais expressões comuns como verdadeiras equivale a representar espontaneamente aquilo que os psicólogos cognitivistas denominam uma "explicação evidencial" [evidential account]. Isto significa representar duas coisas: (1) que a representação que o falante está exprimindo foi causada pelos eventos ou pelo estado de coisas que sua fala descreve, ou seja, que sua representação mental emana do modo como as coisas realmente são; (2) que a fala em questão está expressando essa representação, e não uma outra. Assim, por exemplo, se você me diz "Boyer é um cognitivista", minha presunção automática de que o que você disse é verdadeiro seria construída com base na presunção de que (1) a sua representação mental BOYER É UM COGNITIVISTA foi, de alguma forma, causada pelo fato de Boyer realmente ser um cognitivista; e (2) a sua fala realmente transmitiu essa representação mental. Em outras palavras, eu acredito no que você me diz porque acredito que você sabe do que está falando, e que não está mentindo sobre o que você sabe. A seqüência evidencial, portanto, toma a seguinte forma:

[o fato] causa $\rightarrow$ [a REPRESENTAÇÃO MENTAL] expressa por $\rightarrow$ [a afirmação]

Isso quanto à comunicação diária. O interessante nos procedimentos oraculares, argumenta Boyer, é que eles bloqueiam a possibilidade de construção do estágio representativo da seqüência acima. O que há de importante no transe, nos elementos 'aleatorizantes' (búzios, escápulas rachadas etc.), nas referências a agentes sobrenaturais e congêneres presentes nos métodos divinatórios é que todos eles são meios através dos quais o próprio adivinho de fato se exime da responsabilidade pelo veredito (Boyer 1994:246). Por isso, para usar o exemplo famoso, quando um zande consulta um oráculo, é claro para ele que é o veneno dado às aves, e não o operador do oráculo, que determina o veredito (Evans-Pritchard 
1976:146-149). Segue-se daí que a verdade do veredito não pode ser avaliada por uma correspondência entre o veredito pronunciado e a representação mental do adivinho. O adivinho não pode mentir, porque, rigorosamente falando, ele não fala. Se houver qualquer suspeita de que as representações mentais do adivinho estão de fato infletindo a série causal que leva a um certo veredito, então a ação simplesmente não conta como uma adivinhação (cf. Boyer 1994:207). Dispensando a etapa da representação mental, as 'explicações evidenciais' dos vereditos oraculares correspondem à seqüência:

\section{[o fato] causa $\rightarrow$ [o veredito]}

Em termos peirceanos, os praticantes assumem que o oráculo genuíno é constituído por enunciados indiciais, isto é, enunciados que se supõe causados pelos estados de coisas que expressam, como um sorriso supostamente exprime a boa vontade (Boyer 1990:72-75; cf. Rappaport 1979). Este ponto é da maior importância para Boyer, já que, para ele, o caráter indicial dos vereditos oraculares está no âmago da resposta à questão de por que os praticantes tendem a considerar tais vereditos como verdadeiros. A idéia é que a natureza causal da conexão entre os índices e os fatos que eles descrevem aumenta a probabilidade de os praticantes suporem que o veredito seja verdadeiro. Isto porque, afirma Boyer, desde um estágio muito precoce do desenvolvimento cognitivo humano, as relações causais são representadas como conexões estáveis, de modo que um determinado efeito tende espontaneamente a ser conjugado na mente/cérebro do observador com sua suposta causa. Conseqüentemente, na medida em que as tecnologias oraculares compelem os praticantes a assumir que seus resultados são indiciais, elas tendem também a forçá-los a assumir que esses resultados são verdadeiros. Como a lógica de Boyer, neste ponto, é tão crucial para seu argumento quanto é abstrusa, vale a pena citar suas próprias palavras:

Se se assume que há uma conexão causal entre dois eventos ou estados $C \mathrm{e}$ $E$, uma ocorrência subseqüente de $E$ levará o sujeito a assumir que $C$. [...R]epresentar uma conexão como causal leva à conjetura de que ela corresponde a um padrão estável. [...] Metaforicamente falando, supõe-se que os enunciados [p. ex., os vereditos oraculares] são verdadeiros porque eles são interpretados como sintomas ou índices estáveis das situações que descrevem (1994:251). 
É difícil aceitar esse raciocínio. Tudo que as técnicas oraculares antirepresentacionistas podem fazer é compelir os praticantes a assumir que, se o veredito fosse verdadeiro, ele o seria por ter sido causado imediatamente pelos fatos que descreve, ou seja, o veredito seria o índice de tais fatos. Em outras palavras, o recurso crucial de Boyer à estabilidade da causação é uma petição de princípio. Explicitar a correspondência entre os índices e as conexões causais não pode servir de fundamento para a proposição de que os vereditos oraculares precisam ser tomados como índices, mas apenas para a tautologia de que, se os vereditos assim fossem considerados, eles seriam tidos por verdadeiros. Assim, para retornar aos Azande, o fato de que, quando os vereditos são tidos como verdadeiros, eles são assumidos como sendo causados por, digamos, feitiçaria, não explica de maneira alguma por que os vereditos são tidos como verdadeiros, para começar. De fato, à luz da famosa afirmação de Evans-Pritchard sobre a coexistência das explicações oraculares e de 'senso comum' (ver adiante), a questão permanece: por que os Azande presumem que o veneno mata as aves devido à feitiçaria e não à sua toxicidade?

Pode-se objetar que, longe de ser uma fraqueza, essa subdeterminação é antes uma virtude, uma vez que permite que o argumento cognitivo de Boyer se ajuste ao fato de que os vereditos são freqüentemente postos em dúvida, e não apenas por analistas capciosos, mas também por praticantes céticos. Certamente, em Cuba (como também deve ser o caso em muitos outros lugares), há muitas pessoas que não acreditam de forma alguma em oráculos; os comunistas ideológicos e os cristãos convertidos são particularmente veementes a esse respeito. Talvez ainda mais intrigante seja o fato de que vários praticantes vão às sessões imbuídos daquilo que poderia ser descrito como um espírito agnóstico ou indiferente, explicando, por exemplo, que, embora se interessem pelo que os adivinhos têm a dizer, não estão 'realmente' certos se devem ou não acreditar no que dizem (cf. Bascom 1941). Assim, tendo em vista essas possíveis atitudes, o objetivo da análise não pode ser tornar a verdade dos vereditos perfeitamente garantida - porque, como bem sabem os céticos, ela não o é.

Este é um ponto importante, mas apenas porque ele torna explícitas as afinidades 'clássicas' (no sentido de Viveiros de Castro) da abordagem cognitiva de Boyer. Pois, embora a divergência entre as visões do analista-cético e do praticante-crente sobre o oráculo seja inegável, ela não necessita ipso facto ser interpretada como uma discordância acerca do valor de verdade dos vereditos divinatórios. De acordo com as considerações acima esboçadas, uma alternativa seria interpretar tal divergência 
como uma diferença na intensão dos conceitos utilizados pelas duas partes. Muito do restante deste artigo dedica-se a mostrar que essa alternativa é sugerida pela etnografia da prática oracular. Nesse sentido, defenderei a idéia de que a diferença entre as duas concepções da verdade oracular possui implicações modais: enquanto os céticos entendem que a pretensão dos oráculos à verdade é no máximo contingente, está claro que, para os praticantes, os vereditos oraculares genuínos expressam verdades necessárias. Assim, o que ocorre aqui é, na realidade, uma conversa desencontrada. Apontando ostensivamente para o mesmo referente (a saber, os vereditos oraculares), o cético e o praticante equivocam-se um a respeito do outro. O cético imagina que o praticante simplesmente atribui um valor de verdade diferente aos vereditos (toma por verdadeiro aquilo que ele supõe ser falso), enquanto o praticante considera que, pelo mero fato de pensar na possibilidade de que os vereditos poderiam ser falsos - quanto mais de afirmá-lo — o cético se engana sobre a natureza da pretensão oracular à verdade.

O argumento de Boyer não pode dar conta de tal situação. A bem dizer, poder-se-ia afirmar que, em termos do contraste entre contingência e necessidade, sua abordagem cognitiva trai um preconceito em favor da posição cética. Segundo sua análise, as explicações evidenciais dos praticantes fazem com que um veredito oracular seja representado como verdadeiro porque afirma a existência de um vínculo causal direto com o estado de coisas descrito pelo veredito. Como vimos, isso deixa aberta a possibilidade cognitiva de uma outra explicação causal, que conectaria o veredito não ao estado de coisas que ele descreve, mas a uma causa mais mundana, como a toxicidade do veneno. Mas isso equivale a dizer que, em princípio, os praticantes do oráculo são capazes de representar os vereditos como falsos, o que é uma outra forma de dizer que, também para eles, os vereditos são apenas contingentemente verdadeiros. Veremos que não há como sair desse dilema enquanto se supuser que o mesmo conceito de verdade vale para praticantes e céticos (e analistas). Para nos aproximarmos de um conceito novo, mais adequado de verdade, passo então à etnografia do Ifá em Cuba.

\section{O oráculo de Ifá: um breve esboço}

O Ifá tem um vínculo muito estreito com a Santería, a mais conhecida tradição religiosa afro-cubana. Ambos evoluíram a partir de elementos trazidos por escravos de língua ioruba da África Ocidental, principalmente 
durante o século XIX. A ligação entre os dois mostra-se claramente no compartilhamento de um universo mítico e devocional extremamente rico, como também no fato de serem ritualmente relacionados, já que os babalawos (i. e., os que passaram pela iniciação completa no Ifá) são freqüentemente solicitados a oficiar como adivinhos nos rituais da Santería. O prestígio dos babalawos como adivinhos deve-se a que, diferentemente dos santeros, eles são iniciados no culto de Orula, o deus ioruba do oráculo, a quem têm o privilégio de adorar. De fato, o prestígio dos babalawos é ainda maior, no contexto cubano, pelas credenciais de macho que lhes estão associadas, uma vez que apenas homens heterossexuais são admitidos no culto. Isso posto, ao longo de toda a sua história e até os dias de hoje, o Ifá vem sendo praticado por grupos 'marginais', como os intelectuais cubanos costumam dizer, e em bairros predominantemente nãobrancos de Havana, Matanzas e Cardenas. Meu material vem principalmente de Havana.

Os direitos ao culto do Ifá são alocados conforme restrições iniciáticas. Muito do prestígio do Ifá se deve ao fato de que, para ser completamente iniciada (para se tornar um babalawo, com direito a oficiar no culto), a pessoa tem que passar por uma série de cerimônias de iniciação, cujo objetivo é, em parte, descobrir se Orula irá 'chamar' o neófito ao próximo grau iniciático. A vontade de Orula neste caso - como em todos é expressa através do Ifá, de modo que a cerimônia de admissão a cada novo grau iniciático envolve uma longa sessão oracular (denominada itá). Ser chamado pelo oráculo para "fazer-se a si mesmo Ifá" , como se diz da iniciação* , supõe que se convide alguém já iniciado para presidir a cerimônia como "padrinho" (padrino). Por meio desta cerimônia, os neófitos são recrutados para 'linhagens' rituais que constituem o principal contexto do culto, bem como da tutela da sabedoria mítica e ritual secreta que os babalawos passam a vida "estudando", como dizem.

O elemento mais importante da iniciação é a entrega ao neófito, pelo padrinho, do ídolo consagrado de Orula. De fato, talvez seja mais correto referir-se a este como uma 'divindade-ídolo', uma vez que a parafernália consagrada que os babalawos recebem não é vista como uma 'representação' da divindade, mas como a própria divindade (Bascom 1950; cf. Palmié 2002:166). Orula, portanto, consiste basicamente em um pote de barro que, entre outros itens, contém 21 nozes de palmeira (mano de Oru-

\footnotetext{
* No original, "To make oneself Ifá"; talvez uma tradução mais adequada fosse "ser feito no Ifá'? [N. do T.]
} 
la), as quais são os principais e mais formais instrumentos oraculares que o jovem babalawo, a partir de sua iniciação, está capacitado a usar.

Embora os babalawos executem uma série de serviços cerimoniais e mágicos, o cerne do Ifá é o oráculo, e é sobretudo em sua capacidade de adivinhos que eles são consultados pelos clientes. Os mitos sobre a origem do Ifá narram, essencialmente, como Orula recebeu o dom de interpretar o oráculo, introduzindo assim a ordem em um universo caótico. Nos mitos, Orula é apresentado como um árbitro de assuntos divinos e humanos, que usa seus poderes oraculares para revelar a vontade ou "palavra" de Ifá em benefício de todos que vêm a ele pedir ajuda. Esse papel arquetípico é esperado dos babalawos, tanto na regulação das questões cultuais (tais como aquelas ligadas à iniciação), como em benefício dos clientes que, pagando uma remuneração, vêm visitá-los para esclarecer questões ligadas a saúde, finanças, amor e sexo, problemas com a polícia etc.

O oráculo de Ifá baseia-se em uma série de técnicas concebidas para gerar, de modo aparentemente aleatório, uma dentre 256 configurações possíveis. No caso das sessões mais formais (nas quais irei me concentrar), em que se usam as nozes consagradas, o babalawo obtém esse resultado lançando dezesseis nozes oito vezes consecutivas, de uma maneira que equivaleria a lançar uma moeda oito vezes $\left(2^{8}=256\right)$. As configurações resultantes são chamadas na língua ioruba de oddu, e em espanhol de signos ou letras. Embora os praticantes expliquem que os oddu são um meio de Orula falar "através" do oráculo, enfatizam também que cada um deles é um ser divino de pleno direito; eles são por vezes tidos como manifestações de Orula, como seus "caminhos" (caminos). Além disso, cada oddu tem seu próprio nome e seu próprio signo (daí o termo em espanhol).

Cada sessão envolve o lançamento de uma quantidade de diferentes oddu, de acordo com uma ordem fixa de perguntas. O primeiro lance, entretanto, é o mais significativo, porque determina aquilo que é considerado como o oddu principal da sessão, com base no qual se caracterizarão as circunstâncias pessoais do consulente, seja ele um cliente, um neófito ou qualquer outra pessoa. Mas, antes de revelar o significado do oddu principal, o babalawo lança uma longa série de oddu, com o objetivo de, através de um complexo algoritmo, produzir respostas afirmativas ou negativas a perguntas específicas. A primeira e mais específica dessas perguntas é se o consultante "está", nessa ocasião, iré ou osobbo - grosso modo, se suas circunstâncias são ou não favoráveis. A folclorista cubana Lydia Cabrera traduz esses termos ioruba como "para o bom cami- 
nho" e "para o mau caminho", respectivamente (Cabrera 1996:192). Uma vez descoberto o estado do consulente, o babalawo passa a fazer uma série fixa de perguntas que determinam a natureza e as causas do estado de iré ou de osobbo, assim como os remédios e precauções rituais apropriados.

Quando todas as questões já estão resolvidas, o babalawo inicia a última e mais delicada fase da sessão, na qual o oddu principal, que até agora passou sem comentários, é "falado" (hablar el oddu). Essa idéia de "falar" o oddu decorre do fato de que cada uma das 256 configurações está associada a um grande número de mitos, que os babalawos levam a vida inteira para memorizar. Cada um desses mitos é coloquialmente dito um "caminho" do oddu (camino del oddu). Assim, dependendo da extensão de seu próprio conhecimento, o babalawo começa a narrar um ou mais caminhos do oddu principal, para então interpretá-lo em benefício do consulente. Para dar ao leitor uma idéia do processo, apresentarei um extrato da transcrição de uma sessão a que compareci. Trata-se de uma consulta comum de cliente, em benefício de uma mãe solteira de seus trinta e poucos anos, realizada por meu padrinho Javier, que na época tinha 77 anos de idade, tendo sido iniciado no Ifá em 1968. O oddu principal dessa sessão foi marcado como sendo Obbeyono, e as perguntas a ele endereçadas determinaram que a mulher estava osobbo, com risco de doença por feitiçaria. O remédio receitado foi um colar consagrado dedicado a Babalú Ayé, divindade das doenças, que é muitas vezes identificado "sincreticamente", como eles dizem, com São Lázaro. Ao "falar" o oddu, Javier narrou quatro "caminhos" do Obbeyono. O extrato seguinte apresenta apenas o segundo.

J: Agora, deixe-me dizer uma coisa pra você, pouco importa o seu osobbo São Lázaro vai cuidar disso se você agradecer a ele. As pessoas gostam quando este 'sinal' aparece, e ele tem aparecido muito estes últimos tempos. Ele fala de uma viagem.

C: [risos] Isso é o que todo mundo quer!

J: [dando uma tragada em seu cigarro] Ifá diz que na terra de Lucumí, na África, havia um território que pertencia a Oggún [o temível deus da metalurgia]; com seu facão, este cortava as pessoas que tentavam entrar. Certa vez, ele sentiu que alguém estava invadindo seu território, e então pegou seu facão e foi ao encontro do intruso. Mas quando chegou lá, viu São Lázaro atrapalhado com suas muletas, e ficou com pena; em vez de atacá-lo, começou a abrir caminho para o pobre aleijado com seu facão [...]. Quando as pessoas tiram esse signo em seu itá [a longa sessão oracular conduzida para 
os neófitos como parte de sua iniciação], nós costumamos dizer que elas são viajantes. Mas, neste caso, Orula está dizendo a você que há uma possibilidade de viagem.

C: Quem dera... Toda vez que as coisas melhoram, acontece alguma coisa para atrasar minha vida.

J: É claro, você está osobbo. Vamos ver se Oggún quer alguma coisa para abrir o seu caminho. [joga as nozes etc.] Não. Ele está dizendo que não quer nada. De qualquer maneira, quando for pra casa, você deve cuidar do seu Oggún [referindo-se ao deus-ídolo que ela havia recebido anos antes], dar rum para ele beber, mas não muito, senão ele fica bêbado e não pode mais ajudar você. Todo mundo quer viajar, não é?

Este trecho deixa evidente que a interpretação é uma parte crucial do "falar o oddu". Afinal, o mito sobre Oggún e São Lázaro não mostra nenhuma relação evidente com as perspectivas de viagem da mulher. É apenas porque o babalawo sabe que a viagem pode muito bem estar entre suas preocupações (já que em Cuba, hoje em dia, todo mundo pensa em viajar, como ela mesma confessa abertamente) que o veredito relevante se localiza nessa área. Na verdade, para os próprios babalawos a medida de um bom "orador de Ifá", como eles dizem, é sobretudo sua habilidade em fazer com que os mitos tratem precisamente das circunstâncias pessoais de seus clientes (cf. Matibag 1997:151-152). Javier ilustrou isso para mim com um relato vívido que merece ser citado por completo:

[Para dar uma consulta] você precisa saber como falar — para ser um orador de Ifá - para operar a "metamorfose", como dizemos. [...] Você poderia vir até mim e a partir de uma história eu lhe dizer três coisas. Mas se você for até outra pessoa, ela poderia lhe dizer dez coisas, porque sabe como tirar o máximo proveito do oddu (sacarle provecho). Havia um sujeito [...] famoso quando eu era jovem. Uma vez eu estava com ele em uma [sessão]; ele era arrogante, mas com razão, pois sabia mais que todo mundo [...]. Os outros babalawos estavam falando o oddu — eu também —, mas em certo ponto ele simplesmente se levantou e disse: "agora ouçam!", e virando-se para o neófito [bruscamente]: "a geladeira da sua casa está quebrada!". [O neófito], confuso, disse: "está mesmo". O babalawo dirige-se para os outros: "Vocês ouviram isso?" Esse era seu modo de ensinar. Ficamos imaginando como o Ifá podia falar da geladeira do cara... Então o babalawo se explicou - acho que o oddu era Obara Meyi: "Ifá diz que havia uma ilha onde moravam os pescadores, mas todos os seus peixes apodreciam. Perto dali havia uma outra ilha onde sempre havia neve, e então os pescadores trouxeram neve de 
lá para pôr seus peixes dentro dela." E é assim, através da metamorfose, que ele disse que na casa tinha que haver uma geladeira e, já que o neófito tinha se mostrado osobbo, que ela devia estar quebrada. Viu como funciona?

Seria possível listar uma variedade de maneiras pelas quais os babalawos guardam a prerrogativa da interpretação, vendo-a como elemento crucial de uma sessão bem-sucedida. Poderíamos também mostrar como os clientes têm efetivamente a expectativa de que os adivinhos apliquem as habilidades interpretativas aos seus próprios casos, e como eles costumam fornecer aos adivinhos as informações relevantes para ajudálos a "chegar ao ponto", como me disse um cliente. Embora não tenhamos espaço aqui para isso, há uma questão concernente ao tratamento antropológico desse fenômeno comum - chamemo-lo de "abertura interpretativa". Em uma versão clássica daquilo que Viveiros de Castro chamaria de "solução clássica" ao problema da crença, alguns antropólogos explicam a convicção dos praticantes de que os meios oraculares produzem vereditos verdadeiros, mostrando as sutis negociações intersubjetivas freqüentemente envolvidas na interpretação oracular (p. ex., Bascom 1941; Bohannan 1975; Lévi-Strauss 1963; Sperber 1982; Parkin 1991; Zeitlyn 1990; 1995). A idéia é que os vereditos são como tábulas rasas, nas quais os praticantes inscrevem interpretações que podem, razoavelmente, representar como verdadeiras. A habilidade do adivinho em alcançar esse ar de plausibilidade (de boa ou má-fé) é, portanto, considerada crucial para sustentar a confiança das pessoas na capacidade supostamente misteriosa de revelar a verdade de que os meios oraculares são dotados.

As boas maneiras não são a única razão para recusarmos essa atitude analítica tão comum, de tipo "sou mais esperto que você", perante o praticante do oráculo. Na minha opinião, o que a etnografia mostra é que a prática divinatória gira em torno de uma inversão particularmente bizarra da premissa que subjaz a tal atitude. Pois a premissa é que a atribuição de verdade deve vir após a interpretação, já que, logicamente falando, se os adivinhos e seus clientes devem decidir se o oráculo lhes diz a verdade, devem antes entender o que o oráculo lhes está dizendo. Muito ao contrário, porém, eu afirmaria que aquilo que torna tão especial a verdade oracular é o fato de que os praticantes põem, precisamente quanto a isso, o carro na frente dos bois. Do ponto de vista do praticante, os vereditos divinatórios são algo que vale a pena interpretar justamente porque, antes de tudo, eles têm que ser verdadeiros.

Não posso garantir a validade desse ponto para o caso de todas as formas de prática oracular no mundo; mas no caso do Ifá, pelo menos, ela 
é muito clara. Discutindo essa questão tanto com os babalawos como com clientes não-iniciados, ouvi por diversas vezes duas afirmações, feitas como se fossem máximas auto-evidentes: "Orula não se engana" (Orula no se equivoca) e "em Ifá não há mentiras" (en Ifá no hay mentiras). Já os babalawos, bem, "eles são seres humanos", como me disse um dos afilhados de Javier, "e isso significa que são imperfeitos". Tais comentários não mostram apenas a falácia contida na alegação de que o espectro da verdade divina é construído a partir de projeções interpretativas habilidosas. Eles também sugerem uma conclusão que põe a análise da verdade oracular em uma perspectiva inteiramente diferente. Ou seja, que, enquanto são considerados como genuínos, os vereditos Orula são tidos pelos praticantes não apenas como enunciados verdadeiros, mas como indubitáveis. Pois ao dizer, efetivamente, que os enunciados oraculares que (por uma razão qualquer) se mostram errados ou enganosos não são vereditos genuínos, os praticantes excluem toda possibilidade de eles serem falsos, o que é uma outra maneira de estipular que os vereditos oraculares genuínos só podem ser verdadeiros. Ora, essa questão sobre o oráculo já foi levantada antes, e por ninguém menos que Evans-Pritchard, que chamou famosamente de "elaborações secundárias" as redes de segurança lógicas com que os Azande conseguiam transformar circunstâncias aparentemente falsificadoras em confirmações da infalibilidade de seu oráculo de veneno. A razão por que penso valer a pena recolocar a questão é que, mais como Viveiros de Castro que como Evans-Pritchard, vejo a convicção por parte dos praticantes de que seus oráculos são infalíveis, não como uma conseqüência do caráter fechado de seus pressupostos epistemológicos, mas antes como uma marca da alteridade ontológica a respeito de que tipo de coisa a própria verdade poderia ser.

\section{A necessidade e a premissa desnecessária da representação}

Semelhante possibilidade fica clara quando se considera quão profundamente paradoxais parecem ser as visões dos praticantes sobre a infalibilidade do oráculo, se julgadas da perspectiva das noções comuns de verdade. Tentemos formalizar a observação etnográfica de que os praticantes do Ifá consideram os vereditos de Orula infalíveis em termos da distinção filosófica modal entre verdades necessárias e contingentes. O exemplo clássico de verdade necessária é o enunciado " $2+2=4$ " : afirmar o contrário não seria apenas falso; seria uma contradição em termos, já que uma das propriedades lógicas do número 2 é que, adicionado a si 
mesmo, ele gera o número 4. Um exemplo de verdade contingente é "George W. Bush é presidente"; este enunciado é verdadeiro, mas é claro que, se as circunstâncias houvessem sido diferentes, poderia perfeitamente ser falso. Tendo em mente essas breves definições, notemos o paradoxo. Aparentemente, os tipos de enunciados produzidos pelos oráculos assemelham-se a exemplos perfeitos de contingência. Afinal, enunciados como "sua geladeira está quebrada" ou "uma viagem é iminente" poderiam perfeitamente ser falsos (a geladeira podia estar boa etc.). Entretanto, embora os praticantes, sem dúvida alguma, estivessem dispostos a admitir a contingência de tais enunciados, caso fossem proferidos no decorrer de uma conversa comum, sua posição sobre a indubitabilidade de vereditos genuinamente oraculares implica que os juízos de verdade em questão são, enfim, necessários. E isso simplesmente porque, para eles, afirmar que o enunciado "a geladeira está quebrada" é, ao mesmo tempo, genuinamente oracular e falso, é cair em contradição. Assim, uma vez que, filosoficamente falando, juízos de verdade têm que ser ou contingentes ou necessários (e nunca os dois), encontramo-nos em uma embrulhada. O compromisso de levar a sério a visão dos praticantes nos inclinaria a adotar a idéia de que, apesar das aparências, os vereditos oraculares são verdades necessárias. No entanto, tal visão contradiz nossa compreensão comum da verdade, segundo a qual os vereditos só podem (no máximo!) ser considerados contingentes. De um ponto de vista 'ontográfico', então, só há uma solução: precisamos identificar e então eliminar aqueles pressupostos subjacentes que tornam as concepções comuns de verdade incompatíveis com a posição dos praticantes sobre o oráculo.

Vou tentar ser breve nessa inevitável digressão sobre a filosofia da verdade. Acabei de identificar a noção de contingência como o primeiro ponto problemático para a apreciação da diferença entre as noções oraculares e comuns da verdade. Portanto, se pudermos descobrir o que, em nosso conceito comum de verdade, conduz inevitavelmente à conclusão de que os enunciados oraculares são contingentes, teremos dado um passo importante em direção à caracterização de uma abordagem alternativa da verdade que poderia se harmonizar com a prática oracular.

Entendo que um foco estreito sobre o conceito de contingência nos leva diretamente à distinção central dos pressupostos comuns sobre a verdade, a saber, aquela entre representações e fatos. Com efeito, poderíamos dizer que a noção de contingência só tem sentido a partir dessa distinção corriqueira. Pois um modo de expressar a diferença ontológica entre representações e fatos, i. e., expressar o que os torna especificamente diferentes, seria apontar para um contraste modal: enquanto os fatos 
são apenas reais, as representações podem se referir igualmente a coisas que existem e a coisas que não existem. Por essa diferença apenas, é natural supor que as representações, antes que os fatos, são os veículos apropriados da verdade e da falsidade. Mas se as noções de verdade e falsidade pressupõem as representações como veículos, então o conceito de contingência também o faz, já que sua pertinência depende da distinção entre verdade e falsidade. Como já foi explicado, algo é contingentemente o caso se poderia não ter sido o caso. Mas essa possibilidade negativa é pura função da representação, porque negações de fatos, por definição, só podem surgir como conteúdos representativos, isto é, como aquilo de que tratam as representações. Em outras palavras, a possibilidade de alguma coisa ser falsa (da qual depende a noção de contingência) só pode surgir no plano da representação: não há fatos falsos. Analiticamente falando, portanto, sem um conceito de representação não podemos ter um conceito de contingência.

Mas tal conclusão alerta-nos para uma possibilidade analítica intrigante, embora totalmente contra-intuitiva. Uma vez que, ao tentar entender a concepção de verdade oracular dos praticantes, tropeçamos no conceito de contingência, e uma vez que o conceito de contingência depende da idéia de que a verdade é uma propriedade das representações, não seria então razoável perguntar se este último pressuposto é apropriado quando se trata de analisar a verdade oracular? Valeria a pena, talvez, nos perguntarmos se uma conceitualização alternativa da verdade, que dispensasse inteiramente a idéia de representação, não poderia servir como um arcabouço analítico mais apropriado para a prática do Ifá. Na seção final deste artigo, tentarei desenvolver essa possibilidade.

\section{Movimento e verdade oracular}

Por motivos de espaço, meu recurso à etnografia será, infelizmente, mais breve do que deveria. Vou tomar como ponto de partida a noção de "caminhos", que chama a atenção nos discursos dos praticantes sobre o procedimento do Ifá. Como já mencionei, há duas maneiras como a noção de "caminhos" aparece. Primeiramente, as 256 configurações produzidas pelas nozes de palmeira (os oddu) podem ser elas próprias denominadas "caminhos" do deus-ídolo Orula. De fato, este é apenas um caso específico de uma lógica mais geral no Ifá e na Santería, pela qual cada divindade do panteão é vista como "tendo" uma multiplicidade de "caminhos", cada um dotado de características míticas e rituais. O segundo sentido 
que os "caminhos" assumem no discurso dos praticantes tem a ver com o que Orula diz durante a sessão, mais do que com a maneira como ele aparece. Como já notamos, tanto as opções da boa ou da má sorte que são determinadas de saída (que não irei abordar aqui) como os mitos individuais que são referidos mais no final da sessão (que irei abordar) são pensados como "caminhos".

Quando se pede aos babalawos que expliquem por que os deuses e os mitos devem ser pensados como "caminhos", suas respostas são mais ou menos especulativas, e em todo caso indiferentes; o que é curioso, já que, com sua propensão à sabedoria professoral, os babalawos costumam imaginar que têm resposta para tudo. Isso nos leva a concluir que o conceito de "caminho" não tem, em si mesmo, significado cosmológico; sua importância, penso eu, é ontográfica. O fato de os praticantes considerarem o conceito auto-evidente e apropriado para se referir a dados tão diversos nos diz menos sobre o que eles pensam do que sobre como devemos pensar o que eles dizem. Bem, isso seria talvez dar importância demasiada ao modo de se exprimir de meus informantes, não fosse pelo fato de que as referências a "caminhos" correspondem claramente a duas maneiras cruciais pelas quais o movimento faz parte integrante do processo de adivinhação.

A primeira maneira é a mais clara, e tem a ver com a mecânica da sessão. Como já mencionei, a tarefa de lançar os oddu (isto é, os "caminhos" de Orula) envolve essencialmente um evento caótico através do qual uma configuração singular das nozes é determinada. De um ponto de vista técnico, isso coloca o problema de como introduzir o 'caos' no conjunto das 256 configurações possíveis permitidas pelas dezesseis nozes. A solução, obviamente, é através do movimento. As fronteiras que tornam discretas as 256 configurações se dissolvem por um movimento rápido e contínuo, conforme o babalawo muda as nozes de uma das mãos para a outra.

A segunda maneira como o movimento entra no processo oracular talvez pareça menos evidente, mas meu argumento supõe que ela seja fundamental. Refiro-me ao processo de interpretação, mediante o qual os babalawos "metamorfoseiam" - para usar as palavras de Javier — os "caminhos" míticos do Ifá, de modo a fornecer um veredito relevante para as circunstâncias pessoais do consulente. Como vimos nos exemplos extraídos de minhas notas de campo, a interpretação oracular envolve um processo dialógico, pelo qual certos mitos, que apareciam inicialmente como 'estórias' bastante gerais e opacas, são gradativamente transformados até se aplicarem às circunstâncias imediatas do consulente. Esse 
processo diz respeito à habilidade do babalawo de transformar (ou "metamorfosear") o mito, de modo a torná-lo específico o suficiente para que seja considerado como uma mensagem que "toca no ponto", como diz meu informante. Em outras palavras, a habilidade de se chegar pela interpretação a um veredito verdadeiro ("sua geladeira está quebrada", ou seja o que for) pressupõe a capacidade que os elementos de significação, tais como os mitos, têm de se transformar - digamos então, de se mover. Se isso soa metafórico e vago, é apenas porque o hábito arraigado do representacionismo nos predispõe a imaginar que, ao menos em seu estado puro, os significados devem corresponder a algo discreto e estável, isto é, ao que os filósofos analíticos chamam de "proposições". Mas considerem o que acontece agora, enquanto vocês lêem este artigo. Um fluxo de dados significativos está jorrando deste texto - assim como uma corrente contínua de sons sairia de minha boca se eu o estivesse lendo em voz alta - e é apreendido por vocês como uma espécie de animal mutante que só pode ser domado ou imobilizado por meio de um certo esforço. Somente quando você 'toca no ponto' (e somente se houver um ponto em que tocar) é que o sentido começa a adquirir uma aparência de stasis. Na origem, portanto, o sentido se move - literalmente.

Note-se que essa concepção 'movente' do sentido está totalmente em desacordo com a idéia comum de que os significados são 'representações' que poderiam 'corresponder a' [match] ou 'refletir' os fatos do mundo. Tal correspondência pressuporia que os significados em questão já estão constituídos como 'proposições sobre o mundo', o que é apenas uma outra maneira de imaginar o sentido em um estado de repouso.

O que eu gostaria de argumentar é que o papel central, no Ifá, da noção de transformação pelo movimento pode ser visto como o principal elemento de uma lógica 'movente', com profundas implicações para uma reconceitualização da verdade e da necessidade oraculares. Para dar uma idéia do que quero dizer com 'lógica movente', recuemos uns 65 anos até a famosa distinção de Evans-Pritchard, entre perguntas do tipo 'como' e do tipo 'por que', proposta no contexto de uma interpretação que pode ser vista como exemplo, caracteristicamente discreto, de análise ontográfica. A cabana do cervejeiro Zande pega fogo. Ele consulta o oráculo para descobrir o que aconteceu e este lhe diz que houve bruxaria. Tal resposta, diz Evans-Pritchard, não tem a intenção de substituir ou sequer de competir com uma explicação corriqueira, em termos da seqüência causal de eventos que levaram ao fogo, explicação que os Azande são tão capazes de conceber como qualquer outro povo. Ela só poderia explicar como o fogo começou, ao passo que aquilo que interessa ao cervejeiro 
quando ele vai consultar o oráculo é por que esse infortúnio afetou a ele em particular e nesta ocasião. Em outras palavras, enquanto as explicações comuns contam estórias causais, os vereditos oraculares relacionam acontecimentos com histórias pessoais. Pode-se dizer, portanto, que a adivinhação continua de onde o 'senso comum' parou. Pois, no final das contas, depois de o incêndio da cabana ter sido explicado da maneira mais exaustiva e minuciosa possível, seu proprietário permanece com a questão: "por que eu? por que agora?" A única resposta do senso comum é uma não-resposta: "por coincidência".

A distinção entre 'como' e 'por que', enquanto tal, não é muito importante para meus propósitos aqui, até porque os oráculos de Ifá são de fato consultados para responder a toda sorte de perguntas, algumas sem nenhuma relação com o infortúnio. Em que sentido, por exemplo, perguntas a respeito da ocasião apropriada para uma cerimônia deveriam ser vistas como perguntas do tipo 'por que' e não do tipo 'como'? Bem mais significativas, a meu ver, são duas intuições capitais que subjazem à distinção de Evans-Pritchard. Em primeiro lugar, a noção de que as pretensões divinatórias à verdade relacionam coisas-eventos a histórias pessoais dá muito pano para manga. A diferença entre 'por que' e 'como' gira, em última análise, em torno de uma distinção entre duas ordens de relação. As questões do tipo 'como', já vimos, são respondidas em termos causais, ligando eventos de maneira linear em seqüências lógicas, o conseqüente ao antecedente: "isto aconteceu porque aquilo aconteceu..." etc. Podemos denominar tais ligações de relações de conjunção (ver Figura 1). Perguntas do tipo 'por que', por outro lado, parecem dizer respeito a algo como uma dimensão oculta, espremida 'entre' conjunções lineares; quando todas as cadeias causais estão definitiva e solidamente amarradas, resta ainda espaço bastante para a pergunta extra: "mas por quê?" Essa qualidade 'extra' é apenas produto do deslocamento lógico que ocorre ao se relacionar cadeias causais a dados que estão fora delas — fora por definição, já que meramente postular a existência de outros elos causais manteria a análise no plano do 'como'. 
Figura 1: conjunção (elos causais)

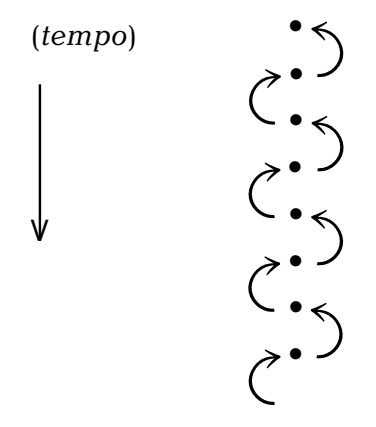

- : evento, ( : elo causal (conseqüente a antecedente)

Mas que tipo de relação poderia ser esta? Uma pista, creio, está na segunda intuição de Evans-Pritchard, a saber, que o senso comum tende a descartar as perguntas divinatórias do tipo 'por que' graças à noção de 'coincidência'. Não obstante sua vacuidade normativa, o conceito é graficamente dinâmico: denominamos 'coincidências' àqueles eventos que constituem a resultante singular de duas ou mais séries causais não relacionadas. (Entro num bar e encontro você 'por coincidência' se os acontecimentos que me trouxeram ao bar são causalmente independentes dos acontecimentos que o trouxeram.) Isso pode parecer uma maneira negativa de caracterizar as relações do tipo 'por que', já que a marca distintiva evidente da coincidência (em oposição à conjunção) é que ela é nãocausal. Porém, uma análise mais abstrata revela a sua face positiva e dinâmica. Em primeiro lugar, a coincidência supõe a interação: relações de coincidência nelas mesmas não geram séries ordenadas, sendo antes constituídas nas interseções de séries causais (ou de seus membros), tal como ilustrado na Figura 2. Em segundo lugar, os pontos de interseção que constituem as relações de coincidência correspondem a eventos dinâmicos, já que representam pontos de encontro de séries em movimento. Isso se segue simplesmente do fato de que as cadeias causais elas próprias incluem eventos, isto é, alterações no tempo, de modo que seus encontros constituem, propriamente falando, colisões temporárias de trajetórias. Pode-se dizer, então, que as coincidências são melhor caracterizadas pelo oxímoro 'interações não-causais'. 
Figura 2: coincidência (interações não-causais)

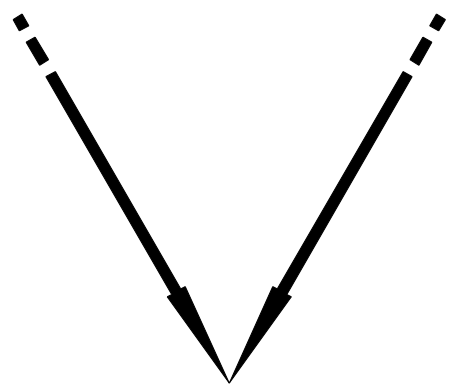

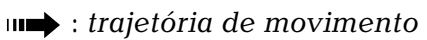

É preciso deixar claro que essas considerações abstratas permitem uma análise que vai além da distinção entre 'como' e 'por quê'. A diferença entre conjunção e coincidência não é uma diferença de significado ou conteúdo (expressa em termos de categorias distintas de questões), e sim uma antítese puramente formal. Se o 'senso comum' trabalha para identificar as conjunções que ligam os eventos às suas causas, o oráculo opera lateralmente, estabelecendo pontos de colisão entre trajetórias causalmente independentes de eventos. De fato, note-se aqui que a distinção pode também ser expressa em termos de uma oposição entre repouso e movimento. Tal como a definimos, a diferença entre conjunções causais e interações não-causais equivale à diferença entre dar prioridade lógica a séries de eventos isolados - ou ao menos distintos, e assim estáveis - , de um lado, e partir de trajetórias contínuas de movimento, de outro. Desse ponto de vista, o senso comum e o oráculo são diametralmente opostos: ao passo que o primeiro tem como dados os 'eventos' enquanto pontos determináveis e deve trabalhar para ligar esses pontos em uma ordem implicitamente temporal formando 'cadeias', o último tem como dado o movimento enquanto matéria-prima, de modo que seu trabalho passa a ser o de chegar até os 'eventos', que nesse caso se constituem como definições temporárias nos vértices do movimento. O conceito de 'lógica movente' refere-se precisamente a essa inversão ontológica, que postula o movimento como primordial, e as entidades estáveis como resultados derivados. 
Dada a etnografia já apresentada, talvez o objetivo da presente análise tenha começado a ficar mais claro. No Ifá, tanto o processo de "metamorfose" no ato de "falar os oddu", pelo qual se chega ao veredito, como o procedimento técnico pelo qual os próprios oddu são obtidos, prestam-se a ser analisados em termos de relações de coincidência entre trajetórias de movimento ou "caminhos" — para usar o termo indígena. Começarei com o caso da interpretação mítica. Já destaquei dois pontos relevantes. Primeiro, que a interpretação é um processo dialógico por meio do qual se faz com que os mitos tratem das circunstâncias do consulente. Segundo, que esse processo é transformador e que, portanto, o sentido dos mitos é mais corretamente representado como estando em movimento. A isso devemos acrescentar que, como as circunstâncias pessoais do consulente também aparecem no processo de interpretação enquanto dados que passam a interagir com o sentido do mito, o sentido dessas circunstâncias também deve ser pensado em termos moventes. Assim, voltando ao extrato de diálogo, o "caminho" mítico que descreve o encontro de São Lázaro com Oggún não precisa ser concebido como fundamentalmente diferente das, digamos, frustrações pessoais da consulente em suas tentativas de viajar. Ambos os dados se referem a eventos ou estados de coisas que são significativos, e podem ser pensados, narrados e transformados em movimento. Portanto, o que temos aqui de fato são dois trajetos de sentido que inicialmente parecem não estar relacionados, e a tarefa do adivinho é fazer com que os dois 'se encontrem' de forma a produzir um veredito que "toca no ponto". Assim, está claro que estamos diante de uma relação de coincidência (ver a Figura 3).

Figura 3: coincidência na interpretação oracular

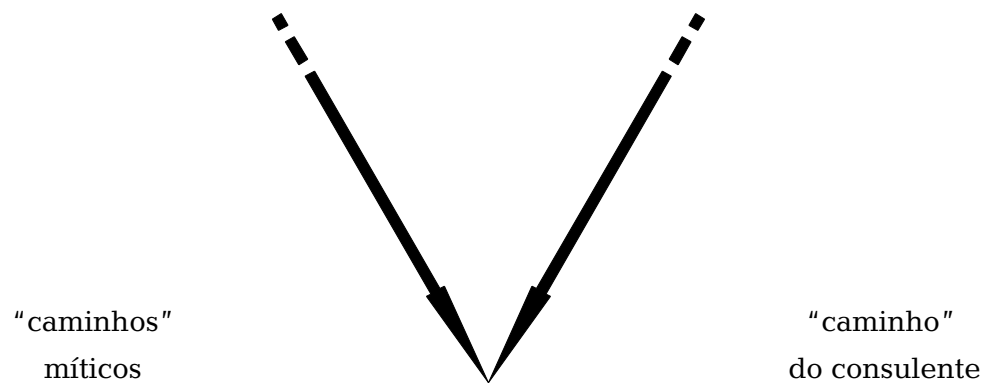

veredito 
Algumas afirmações concernentes à emergência movente dos vereditos oraculares podem ser feitas a partir da Figura 3. Elas concluem nossa discussão sobre a noção de verdade. A primeira é que, de acordo com esse modelo, os vereditos surgem como eventos singulares. Ora, uma tal afirmação pode parecer dizer respeito antes à epistemologia do que à ontologia, visto que se apresenta como uma resposta à questão sobre como surgem as pretensões oraculares à verdade, e não sobre que tipo de coisas elas são. Mas isso seria um engano. Como enfatizei diversas vezes, o próprio processo de adivinhação, bem como o que dizem os praticantes sobre ele, não deixa dúvidas sobre o fato de que, no Ifá, a interpretação é constitutiva da definição de verdade oracular. Portanto, se o processo de interpretação pressupõe a motilidade do sentido, então o movimento é também a base ontológica da verdade oracular enquanto tal. Assim, e isso é realmente o cerne do presente argumento, a verdade deve neste caso ser precisamente definida como o evento resultante do encontro de trajetórias causalmente independentes de sentido, o que é exatamente o tipo de encontro que os adivinhos são capazes de gerar, por meio da metamorfose interpretativa.

O segundo ponto a notar é que tal definição de verdade tem conseqüências para a questão da necessidade. Tendo definido a verdade como um tipo de evento, podemos agora nos perguntar se esse evento é contingente ou necessário. Ora, olhando para a Figura 3, pode-se ficar tentado a dizer que os vereditos são contingentes, uma vez que, se as trajetórias tivessem seguido um curso diferente, o que seria perfeitamente possível, elas poderiam ter se cruzado em um ponto diferente, ou nem ter-se cruzado. Entretanto, eu diria que existe uma perspectiva segundo a qual, parafraseando Bourdieu (1990:39), isso é um escorregão "do modelo da realidade para a realidade do modelo". Essa perspectiva é a perspectiva do próprio movimento.

Consideremos o que, do movimento, é reduzido ou pressuposto, para fins de sua representação gráfica. Para indicar o movimento sobre o papel, basta uma linha que mostre sua trajetória e uma pequena seta na extremidade para marcar sua direção: como só os movimentos têm direção, isso é suficiente. Mas por que uma linha é apropriada para representar uma trajetória? A resposta, claro, é que trajetórias são necessariamente contínuas, e isto porque os movimentos possuem um momentum, um poder intrínseco que os 'mantém em marcha'. Mas, se pensarmos bem, veremos que a continuidade das trajetórias representadas graficamente é apenas uma maneira muito tímida de exprimir o momentum. Isso não é de surpreender, pois tota simul as representações sobre o papel 
têm que ser 'econômicas': elas não se movem nelas mesmas e, portanto, não podem ter realmente um momentum. Mas a economia tem um preço, e o preço aqui deve ser pago na moeda corrente dos conceitos modais. O importante sobre o momentum não é apenas que ele torna o movimento ao mesmo tempo contínuo e direcional, mas também que o faz por necessidade: o momentum descreve a compulsão interna do movimento. A melhor maneira de compreender isso, creio, é pela cinemática: imagine-se trocando a perspectiva panorâmica dos diagramas por uma câmera que estivesse na ponta de uma trajetória móvel, como nas transmissões de corridas de Fórmula 1 a partir do cockpit de um concorrente. O que você vê agora não é nem um pouco contingente: seu campo de visão imanente é ditado a cada instante pela propulsão da própria trajetória. O que, anteriormente, parecia um curso possível (contingente) entre muitos, parece agora o único curso possível, porque o momentum do movimento - sua propulsão em uma direção - leva você com ele. Com o momentum, pode-se dizer, o movimento acarreta sua própria necessidade.

É preciso enfatizar que o que precede constitui um afastamento radical em relação à concepção representacionista, visto que a verdade assim definida não é aquela a que estamos habituados. Arrisco-me a chamar a verdade em questão de 'revelatória': o que está em debate aqui não é a veracidade do modo como as coisas são pensadas ou representadas, mas a capacidade que as coisas têm - coisas moventes - de revelar-se umas às outras, quando entram em relação por sua proximidade mútua. Mais uma vez, isso não deve ser lido como uma metáfora, pois as 'coisas' nesse contexto não são 'objetos' ou 'entidades', mas dados significativos que se manifestam em movimento, e como movimento, e que interagem nessa qualidade. Tomada nesse sentido, a noção de 'revelação' nada tem de misteriosa. Imagine uma conversa corriqueira entre nós dois: suas idéias revelam-se a mim ao colidirem com as minhas e assim as transformarem, justo como minha análise do Ifá revela-se a você quando você a refaz em 'sua cabeça'. Dispensando qualquer mistério, podemos descrever as pretensões oraculares à verdade como 'revelatórias' em função da modificação que sobrevém quando dois trajetos de sentido inicialmente independentes são postos em contato. Não foi por acidente que o eureca! newtoniano sucedeu a uma colisão significativa com uma maçã: são exatamente esses momentos de 'eureca', escritos com letras pequenas nas páginas dos diários pessoais, que o oráculo, em sua motilidade, engendra.

Essa definição da verdade daria a impressão de um misticismo vazio? Talvez; mas argumento que tal impressão se deve ao fato de que pen- 
sar a verdade dessa forma chama a atenção justamente para aqueles aspectos dos juízos de verdade que as teorias representacionistas tomam por evidentes (isso responde à 'vacuidade') e, assim, por obscuros (e isso, ao 'misticismo'). Consideremos por um momento a explicação representacionista. A verdade, diz-nos o senso comum, é um atributo daquelas representações que refletem os fatos. Portanto, a atribuição de valor de verdade envolve uma comparação entre representações e fatos a fim de estabelecer uma 'correspondência' ou 'coerência', dependendo das preferências filosóficas ${ }^{6}$. Entretanto, a noção de comparação aponta para uma profunda circularidade aqui. Logicamente falando, a comparação pressupõe dados que já 'lhe' estão dados como comparáveis, pois a comparação não é algo que se pode atualizar de modo indeterminado: comparar é sempre escolher comparar algo com algo. Portanto, no caso da atribuição de valor de verdade, a comparação entre a representação " $p$ " e o fato $p$ (isto é, o acordo verificativo) já pressupõe que $p$ é selecionado como o dado correto com que se há de comparar " $p$ " (certo que se pode descobrir que esse era o dado errado, mas a questão é precisamente que o emparelhamento verificativo sempre tem que começar de algum lugar). Ora, é claro que essa afirmação da comparabilidade é ela mesma implicitamente comparativa: ao supor que " $p$ " e $p$ são passíveis de comparação, já se os está comparando - de fato, já se está estabelecendo um emparelhamento inicial entre eles. Mas, da definição representacionista da verdade, segue-se que estabelecer esse emparelhamento entre uma representação e um fato (ainda que inicial) é assumir tacitamente uma posição em relação à verdade dessa representação ${ }^{7}$. A circularidade da definição é evidente: uma correspondência verificativa pressupõe uma comparação que pressupõe uma correspondência verificativa que pressupõe uma comparação etc.

É importante frisar aqui que essa circularidade surge associada a um conflito conceitual mais profundo. Por um lado, a explicação representacionista pressupõe que a verdade é uma propriedade relacional, na medida em que a atribui a representações que possuem uma certa relação de acordo com os fatos. Por outro, os relata envolvidos são vistos como pertencentes a campos ontológicos distintos (representações versus fatos). O problema que surge então é típico das ontologias dualistas em geral, a saber, o da 'interação': como exemplares [tokens] de tipos ontológicos distintos podem ser relacionados entre si (como se supõe ser o caso das correspondências verificativas)? É à luz desse problema que a explicação representacionista ao mesmo tempo toma por dado e obscurece as correspondências verificativas 'iniciais' a que aludi. É preciso pressupor 
ligações iniciais entre as representações e os fatos para tornar possível as relações de correspondência que estabelecem as atribuições de verdade. Mas essas ligações precisam permanecer não teorizadas, porque sua condição ontologicamente anômala de serem 'meio-representações, meiofatos', por assim dizer, se tornaria evidente sob a luz da análise.

Esse tipo de problema, é claro, freqüentemente tem solução, e meu argumento a respeito da verdade divinatória certamente não concerne à questão filosófica sobre se o dilema representacionista tem ou não solução. Afirmo apenas que o oráculo de Ifá assenta sobre uma concepção alternativa da verdade, e que essa alternativa pode ser definida conceitualmente em termos de sua liberdade em relação a esse dilema particular. A razão disso é que o que não é levado em conta na explicação representacionista - a posição 'inicial' de verdade - é aqui trazido ao primeiro plano, como constituindo a base da conceitualização bastante diferente da verdade que propus anteriormente. Se a verdade resulta de 'encontros' entre trajetórias moventes de sentido, não há nenhuma anomalia ontológica a combater e, portanto, também não há nenhuma circularidade: diferentemente das 'correspondências', os encontros em questão são constituídos como relações entre exemplares de um mesmo tipo ontológico.

Poderíamos resumir o argumento sobre a verdade oracular por meio de uma resposta ao tipo de objeção judiciosa feita pelos, digamos, químicos. Ainda que todos esses meus laboriosos argumentos fossem válidos, não seria entretanto evidente, diriam eles, que os adivinhos e seus clientes estão tão interessados em saber quais são os fatos do mundo como qualquer outra pessoa? Quando um babalawo anuncia que uma bruxa está enfeitiçando um seu cliente, ou que a geladeira de seu outro cliente está quebrada, não está ele fazendo afirmações sobre como andam realmente as coisas no mundo, ou seja, afirmações sobre fatos? E não será esta a razão muito simples pela qual os praticantes estão interessados naquilo que o oráculo lhes diz? Bem, minha resposta é "não". Mas "não", não porque os praticantes não estejam interessados em descobrir coisas sobre o mundo, e sim porque essas descobertas não são adequadamente descritas pela noção de 'determinar os fatos', ou ao menos não enquanto essa noção implica um processo de comparar idéias 'sobre' o mundo com o modo como o mundo 'realmente' é. Vereditos são antes pretensões temporárias à verdade, que surgem como e quando o mundo, por assim dizer, revela-se a si mesmo. Essas revelações são 'descobertas' no sentido pleno, porque permitem aos praticantes não apenas ponderar as questões que lhes concernem, mas também entender sua significância. As- 
sim, quando, por exemplo, o arrogante babalawo da estória de Javier exclamou que a geladeira do consulente devia estar quebrada, ele não estava demonstrando o poder de previsão do oráculo. O fato de a geladeira estar realmente quebrada dá uma boa estória, mas, afinal, a consulente não precisava do oráculo para descobrir isso. O babalawo tampouco iria considerar-se um fracasso se a consulente tivesse respondido que a geladeira andava bem - ele simplesmente iria projetar o problema em termos de dificuldades passadas ou futuras, assim como Javier fez em relação à viagem de seu consulente. O que o babalawo estava demonstrando era a habilidade do oráculo em revelar até mesmo dados aparentemente insignificantes e estabelecê-los como constituintes necessários das circunstâncias do consulente - como dados, em suma, aos quais se deve estar atento mais por uma questão de necessidade metafísica que de prazer hermenêutico.

Para concluir, defenderei essa hipótese contra uma objeção muito séria. No pé em que deixei as coisas, parece que todos os dados significativos devem a fortiori ser interpretados também como 'verdadeiros' sempre que são relacionados uns com os outros; uma tal conseqüência certamente tornaria vazia essa noção de verdade. De fato, se minha análise dá sentido à idéia de que os vereditos oraculares são necessariamente verdadeiros, então por que não tornar todas as pretensões à verdade necessárias? Mas aí, de que serviria consultar os adivinhos?

Neste ponto podemos simplesmente agüentar firmes e admitir que, na medida em que são vistas com base em uma premissa movente, todas as colisões de trajetórias de sentido são ipso facto (e necessariamente) verdadeiras. Mas o fundamental é que a razão pela qual as pretensões à verdade não são, em geral, assumidas automaticamente como verdadeiras nessa acepção é que apenas muito poucas dentre elas estão explicitamente baseadas em uma lógica movente. Assim, retomando um exemplo anterior, se estivermos conversando, as suas idéias podem se revelar ao colidirem com as minhas, isto é, podem constituir eventos de verdade segundo a concepção movente. Mas isso não me impede de fazer abstração das trajetórias que levam a esses 'encontros' e representar suas idéias como enunciados de 'proposições' distintas sobre as coisas. De fato, talvez se possa dizer que tais tipos de pressupostos representativos dominam meu pensamento durante nossa conversa, e que as considerações moventes permanecem em latência, como uma condição de fundo. Podese argumentar que isso se deve ao fato de que o molde representacionista enquadra o pensamento em geral, havendo boas razões para que seja assim, inclusive boas razões evolutivas: a capacidade de ajustar nossos 
pensamentos ao nosso meio ambiente (isto é, de julgar as representações estáveis quanto à sua veracidade) é uma condição indispensável para agir de maneira eficiente e, em última instância, para 'sobreviver'. Certamente, os cubanos fazem isso o tempo todo, como o resto de nós, e como fazem os Azande.

Mas minha análise sugere que esse tipo de cálculo da verdade não é apenas diferente do cálculo movente, mas também incompatível com ele. Daí segue-se uma cláusula “ou bem/ou bem", pela qual a atribuição representacionista de verdade inevitavelmente eclipsa as trajetórias em colisão e vice-versa, pois o ato de isolar um evento de verdade movente, tornando-o uma proposição representativa, é apenas um modo de separá-lo das trajetórias de movimento que o engendraram e apresentá-lo como uma abstração discreta. Assim, o domínio do pensamento representativo implanta-se em detrimento dos eventos de verdade moventes, obviando-os como premissas ocultas. Portanto, a descrição movente da verdade evita a trivialidade não por uma restrição de sua aplicabilidade geral, mas porque sua pertinência encontra-se, normalmente, estabelecida.

Penso que aquilo que distingue a dialética interpretativa do Ifá de uma conversa comum é simplesmente o fato de que os procedimentos oraculares maximizam meticulosamente a possibilidade de tratar os vereditos como eventos de verdade moventes, e assim resistem, de certa forma, ao domínio da representação. Esse, creio, é o papel crucial da técnica caotizante de jogar nozes de palmeira para chegar aos oddu. Pois a coincidência é fundamental para esse processo, e os vereditos dos adivinhos giram em torno desse fundamento, ditado pelo procedimento oracular e por sua tecnologia do movimento. Os lances, portanto, são eventos de verdade por excelência, uma vez que eles são equilíbrios temporários resultantes de interações não-causais entre movimentos singulares.

Ou será que isso tudo é demasiadamente psicodélico? Mesmo que aceitemos que o modelo movente da verdade é defensável sob determinadas circunstâncias, o certo é que eventos puramente físicos como o atirar de nozes de palmeira não dão conta do recado: diferentemente da interpretação que eles suscitam, os lances não reúnem trajetórias significativas enquanto tais (que sentido poderia haver em um mero movimento das mãos ou em um punhado de nozes?). Com efeito, nesse modo de ver, o fato de os praticantes estarem prontos a atribuir tanta significância a resultados 'meramente' acidentais (em virtude dos "caminhos" elaboradamente significativos de cada oddu) poderia ser tomado como uma prova do caráter dogmático e arbitrário da crença oracular. Entretanto, essa objeção equivale a uma recusa peremptória em levar a sério a premissa 
movente do Ifá. Os mitos do oddu só aparecem como apêndices semióticos arbitrários dos movimentos 'puramente' físicos se assumirmos que o sentido é separável de suas 'manifestações' materiais ${ }^{8}$. Mas tal pressuposição reitera a ontologia representacionista ao insistir que o sentido só pode ser pensado como uma abstração. Minha análise nega tal coisa. Como, segundo o pressuposto movente, podemos aceitar que os significados fazem parte do mundo, também podemos aceitar que partes do mundo (como mãos em movimento ou configurações de coquinhos) sejam significados - não enquanto signos que 'têm' sentido, mas enquanto manifestações diretas de sentido, pura e simplesmente. O problema passa a ser então o de revelar que sentidos são manifestos pelos movimentos dados, e isso, como já vimos, é uma questão de fazer convergir 'por coincidência' trajetórias de significados relevantes, para produzir um evento de verdade. Os lances oraculares fazem exatamente isso, e o fazem necessariamente.

Recebido em 17 de março de 2003

Aprovado em 29 de junho de 2003

Traduzido por Déborah Danowski

Martin Holbraad, doutor pela Cambridge University (2002), é atualmente pesquisador do Pembroke College, Cambridge. 


\section{Notas}

* O presente artigo apóia-se largamente em um argumento desenvolvido de maneira mais sistemática em minha tese de doutorado. Agradeço aos membros do Senior Seminar de Cambridge, por seus valiosos comentários a uma versão anterior deste. Sou grato também a Caroline Humphrey, Peter Lipton, Morten Pedersen, Rafael Robaina e Alan Strathern por seus comentários às várias versões posteriores do texto, bem como a Michael Houseman e a um parecerista anônimo de Mana, cujos comentários à penúltima versão foram fundamentais. O arcabouço meta-antropológico do argumento ergueu-se sobre uma série de mensagens eletrônicas trocadas com Eduardo Viveiros de Castro; sou-lhe imensamente grato por seus comentários e encorajamento em todas as fases da redação. Registro igualmente meus agradecimentos ao Economic and Social Research Council pelo financiamento de meu trabalho de campo em Cuba, assim como ao Centro de Antropología pela hospedagem em Havana

1 O debate sobre a verdade divinatória transcende os limites disciplinares da antropologia (ver, p. ex., Cicero 1997; Jung 1989; Detienne 1996). Na antropologia, além dos argumentos recentes de Boyer, que analisarei adiante, a questão tem uma longa história (p. ex., Evans-Pritchard 1976 [1937]; Park 1963; Fortes 1966; Bascom 1991[1969]; Turner 1975; Jackson 1989; Zeitlyn 1990; 1995; 2001). De modo geral, essas discussões podem ser descritas como uma espécie do gênero antropológico "debates sobre 'crenças aparentemente irracionais'" (Sperber 1985). Embora eu provavelmente esteja em excelente companhia ao considerar o conceito de racionalidade, nesse contexto, analiticamente pernicioso, apego-me à fórmula de Sperber por razões heurísticas. Ela é útil porque localiza 'o problema', não nas próprias crenças, mas no modo como elas nos aparecem — isto é, como 'crenças' (cf. Needham 1972; Boyer 1994:229).

2 O adjetivo "não verdadeiro" é aqui preferível a "falso", pois permite incluir, como uma variação da solução clássica, a idéia bastante influente de Sperber segundo a qual quaisquer "crenças aparentemente irracionais", como todas as expressões "simbólicas", não são exatamente falsas, mas, antes, vazias, no sentido de não corresponderem a proposições determináveis que pudessem ser julgadas quanto à sua verdade ou falsidade (Sperber 1985).

3 A extensão de uma expressão é sua referência. A intensão é mais difícil de definir; mas, para nossos propósitos, pode-se entendê-la como uma descrição dos critérios suficientes e/ou necessários para se determinar a extensão de uma dada expressão (cf. Chalmers 2002). Assim, por exemplo, se pergunto a você o que é um pecari e você aponta para um ("lá está um!"), você está me dando o sentido de 'pecari' em termos de sua extensão. Mas se você me explicar que um pecari é um tipo de porco que vive na América do Sul, estará me dando a intensão do termo. De maneira vaga, podemos dizer que a extensão de um termo depende de considerações empíricas, ao passo que sua intensão depende de considerações conceituais. 
4 Contrariamente talvez às aparências, a posição de Viveiros de Castro é tão distante do relativismo quanto o é da abordagem 'clássica' (da qual o relativismo é, na verdade, uma variante - ainda que a mais liberal das variantes). $\mathrm{O}$ relativismo pode ser definido sumariamente pela idéia de que povos diferentes vêem o mundo de modos diferentes. O que Viveiros de Castro afirma é, antes, que povos diferentes vivem em mundos diferentes. Novamente, a diferença pode ser descrita pela distinção entre epistemologia (envolvendo discrepâncias extensivas) e ontologia (que diz respeito à alteridade intensiva). Cf. Viveiros de Castro (1998a; 1998b).

5 Note-se que comparações similares já foram feitas antes, notadamente por Jules-Rosette (1978), Jackson (1989) e Boyer (1990).

6 Observe-se que não se trata apenas de uma questão epistemológica sobre como se pode chegar aos juízos de verdade, mas antes da definição do que é a verdade enquanto tal.

7 Para qualquer pessoa remotamente familiarizada com a literatura filosófica sobre a verdade, esse modo de expor o problema soará estranho: o 'emparelhamento inicial' que descrevo é o que a maioria das pessoas chama "referência". A intuição comum sobre isso é que as representações são verdadeiras/falsas na medida em que (1) contêm algum tipo de expressão referencializante (um nome, uma descrição, um token-reflexive etc.) e (2) combinam essa expressão referencializante com uma propriedade, uma relação etc. O juízo "você é iré", por exemplo, contém o referencializante "você" e o combina com a propriedade de ser iré. Ora, na explicação representacionista, "você é iré" é verdadeiro se e somente se você for iré. Mas a razão pela qual o fato de você ser iré é considerado como o fato verificativo é que a representação "você é iré" tem a propriedade semântica de ter você como um referente. Assim, o poder semântico ou representação, isto é, a habilidade de se referir a coisas sem fazer sobre elas juízos de verdade, torna a comparação uma premissa não-circular na definição da verdade.

Mas essa saída é superficial, porque a circularidade da explicação representacionista também pode ser recolocada em termos de referência. A única diferença é que, quando se trata da referência, o 'emparelhamento' não diz respeito 'a fatos', mas a 'objetos' (interpretados de maneira ampla de forma a incluir coisas, pessoas, conceitos ou o que mais se quiser na classe dos referentes). Por exemplo, "você" tem uma referência (relativa a seu contexto etc.) enquanto você lhe corresponde como coisa no mundo, assim como "você é iré" é verdadeiro enquanto corresponde ao fato de você ser iré (para uma exposição formal desse paralelo, ver Horwich 1998:108). Mas a correspondência referencial é uma comparação tanto quanto a correspondência verificativa e, portanto, está sujeita à mesma circularidade: uma correspondência referencial inicial tem que ser postulada etc. 
8 A alegada distinção ontológica é análoga à encontrada em nossa discussão sobre a interpretação oracular. Se lá o representacionismo equivalia a assumir um abismo ontológico entre as representações e o mundo (ou seja, uma questão concernente à metafísica da semântica), aqui a distinção é feita entre as representações e os veículos mundanos através dos quais elas são expressas (i. e., no nível semiótico: significado versus significante). Entretanto, uma vez que nossa análise movente nega uma premissa que essas variantes do representacionismo têm em comum - a saber, que os sentidos são abstratos —, ela também serve como uma alternativa defensável ao representacionismo 'semiótico'. Desse ponto de vista, os oddu não são significantes arbitrários de sentidos (significados) abstratos, e o sistema dos 256 oddu não constitui um 'código' semiótico. Antes, a relação entre a manifestação material dos oddu durante a sessão e seu sentido tal como expresso nos "caminhos" míticos pode ser pensada como análoga à relação entre uma pessoa e sua personalidade: não há arbitrariedade, porque o oddu simplesmente é seu sentido, para aqueles que estão familiarizados com ele (i. e., os babalawos que "estudam"). Daí o fato de cada oddu ser propriamente considerado uma divindade de pleno direito. Assim, na medida em que os oddu em Cuba são comumente chamados de "signos do Ifá" (signos), então esses signos, literalmente, para os praticantes, representam a si mesmos, para usarmos a famosa expressão de Roy Wagner (1986). 


\section{Referências bibliográficas}

BASCOM, William R. 1941. "The sanctions of Ifa divination". Man, LXXI $(1 / 2): 43-53$.

_ 1950. "The focus of Cuban Santeria". Southwestern Journal of Anthropology, 6:64-68.

. 1991 [1969]. Ifa divination: communication between gods and men in West Africa. Bloomington: Indiana University Press.

BOHANNAN, Paul. 1975. "Tiv divination". In: J. Beattie e R. G. Lienhardt (eds.), Studies in social anthropology. Oxford: Clarendon Press.

BOURDIEU, Pierre. 1990. The logic of practice (trans. Richard Nice). Cambridge: Polity Press.

BOYER, Pascal. 1990. Tradition as truth and communication: a cognitive description of traditional discourse. Cambridge: Cambridge University Press.

.1994. The naturalness of religious ideas: a cognitive theory of religion. Berkeley: University of California Press.

. 2000. "Functional origins of religious concepts". Journal of the Royal Anthropological Institute, 6(2): 195-214.

.2001. Religion explained: the evolutionary origins of religious thought. London: Random House, New York: Basic Books

CABRERA, Lydia. 1996 [1980]. Yemayá y Ochún. Miami: Ediciones Universal.

CHALMERS, David J. 2002. "On sense and intension". In: J. Tomberlin (ed.), Philosophical perspectives 16: language and mind. Oxford: Blackwell. CICERO, Marcus Tullius. 1997. Nature of the gods \& On divination (trans.
C.D. Yonge). Essex: Prometheus Books Publishers.

DETIENNE, Marcel. 1996. The masters of truth in Archaic Greece (trans. J. Lloyd). London: Zone Books.

EVANS-PRITCHARD, E. E. 1976 [1937]. Witchcraft, oracles, and magic among the Azande (versão resumida por E. Gillies). Oxford: Clarendon Press.

FORTES, Meyer. 1966. "Religious premises and logical technique in divinatory ritual". Philosophical Transactions of the Royal Society of London, Series B, 251:409-422.

HORTON, Robin. 1967. "African traditional thought and Western science". Africa, 37(1):50-71 e 37(2): 155-187.

HORWICH, Paul. 1998. Truth (2 $2^{\text {nd }}$ ed.). Oxford: Clarendon.

JACKSON, Michael. 1989. Paths toward a clearing: radical empiricism and ethnographic inquiry. Indianapolis: Indiana University Press.

JULES-ROSETTE, Bennetta. 1978. "The veil of objectivity: prophesy, divination, and social inquiry". American Anthropologist, 80(3):549-570.

JUNG, Carl G. 1989b [1951]. "Foreword". In: The I Ching or Book of changes. London: Arkana.

LÉVI-STRAUSS, Claude. 1963. Structural anthropology (trans. Jacobson \& Grundfest Schoepf). London: Allen Lane the Penguin Press.

MATIBAG, Eugenio. 1997. "Ifá and interpretation: an Afro-Caribbean literary practice". In: M. Fernández Olmos e L. Paravisisni-Gebert (eds.), Sacred possessions: Vodou, Santería, Obeah, and the Caribbean. New Brunswick: Rutgers University Press. 
NEEDHAM, Rodney. 1972. Belief, language and experience. Chicago: University of Chicago Press.

PALMIÉ, Stephan. 2002. Wizards and scientists: explorations in Afro-Cuban modernity and tradition. Durham: Duke University Press.

PARK, George K. 1963. "Divination and its social contexts". Journal of the Royal Anthropological Institute, 93: 195-209.

PARKIN, David. 1991. "Simultaneity and sequencing in the oracular speech of Kenyan diviners". In: P. Peek (ed.), African divination systems: ways of knowing. Bloomington \& Indianapolis: Indiana University Press.

SPERBER, Dan. 1982. "Apparently irrational beliefs". In: M. Holis e S. Lukes (eds.), Rationality and relativism. Cambridge, MA: MIT Press.

_.1985. On anthropological knowledge. Cambridge: Cambridge University Press.

.1996. Explaining culture: a naturalistic approach. Oxford: Blackwell Publishers.

TURNER, Victor. 1975. Revelation and divination in Ndembu ritual. Ithaca: Cornell University Press.

VIVEIROS DE CASTRO, Eduardo. 1998a. "Cosmological deixis and Amerindian perspectivism". Journal of the Royal Anthropological Institute, 4(3):469-488.
— . 1998b. Cosmological perspectivism in Amazonia and elsewhere (Conferências apresentadas ao Dept. of Social Anthropology, University of Cambridge). .2002. "O nativo relativo". Mana, 8(1):113-148.

WAGNER, Roy. 1972. Habu: the innovation of meaning in Daribi religion. Chicago: Chicago University Press. . 1986. Symbols that stand for themselves. Chicago: Chicago University Press.

ZEITLYN, David. 1990. "Prof. Garfinkel visits the soothsayers: ethnomethodology and Mambila divination". Man (N.S.), 25:654-666. . 1995. "Divination as dialogue: negotiation of meaning with random responses". In: E. N. Goody (ed.), Social intelligence and interaction. Cambridge: Cambridge University Press.

.2001. "Finding meaning in the text: the process of interpretation in text-based divination". Journal of the Royal Anthropological Institute (N.S.), 7:225-240. 
Resumo

O objeto deste artigo é o conceito de verdade tal como se articula no oráculo de Ifá cubano; seu objetivo é ilustrar a fecundidade de um "método ontográfico" que procure mapear as premissas ontológicas do discurso nativo por meio da produção de conceitos que, não sendo os conceitos nativos eles mesmos, constituam equivalentes aproximados destes. Enfatizando a afirmação dos praticantes de que o Ifá é infalível, propõe-se que os vereditos divinatórios devem ser entendidos como verdades necessárias, isto é, como enunciados que não poderiam não ser verdadeiros. Em seguida, mostrando que, do ponto de vista das concepções comuns de verdade, a necessidade modal dos oráculos só pode parecer um absurdo dogmático, procura-se avançar uma conceitualização alternativa que concorde com as convicções dos informantes, examinando um complexo de conceitos e práticas associados ao oráculo a fim de avaliar as premissas que garantem a verdade e sua emergência na prática do Ifá.

Palavras-chave Oráculos, Verdade, Ifá, Ontologia, Cognição
This article analyzes the concept of truth as employed by Ifá oracles in $\mathrm{Cu}$ $\mathrm{ba}_{\text {; }}$ its aim is to illustrate the fertility of an 'ontographic method' dedicated to mapping the ontological premises of native discourse through the production of concepts which, while not the native concepts themselves, comprise close equivalents to them. Emphasizing practitioners claims that the Ifá is infallible, it is proposed that divinatory verdicts should be understood as necessary truths, that is, as statements which cannot not be true. Then, after showing that from the viewpoint of common place conceptions of truth, the modal necessity of oracles can only appear a dogmatic absurdity, I propose an alternative conceptualization which agrees with the convictions of informants. This involves examining a complex of concepts and practices linked to the oracle in order to evaluate the premises which ensure truth and its emergence in Ifá practice.

Key words Oracles, Truth, Ifá, Ontology, Cognition 